Historic, Archive Document

Do not assume content reflects current scientific knowledge, policies, or practices. 



\section{THE NEW BLACK GRAPE}
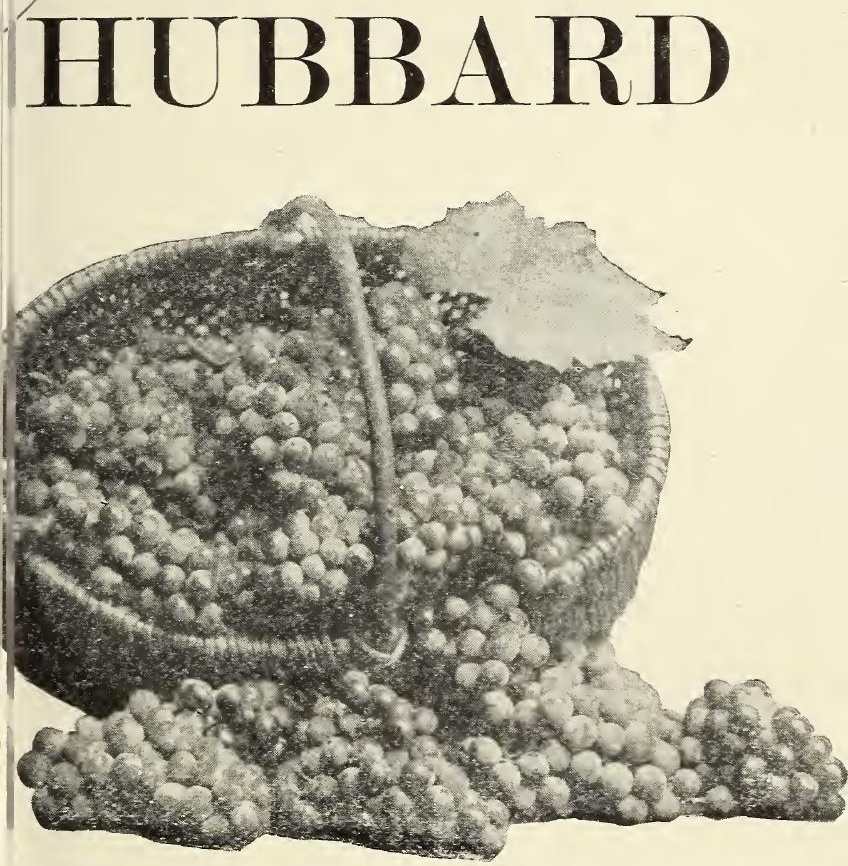

INTRODUCED BY

\section{T. S. HUBBARD CO. FREDONIA, N. Y.}

Growers of

Grape Vines and Small Fruit Plants Established Eighteen Sixty Six 


\section{THE NEW BLACK GRAPE}

\section{HUBBARD}

\section{DESCRIPTION}

2

UALITY sweet and delicious having that fine and pleasant flavor approaching the European or Vinifera Grapes. Seeds few and small which separate freely from the tender pulp. Skin thin and firm. Berries and bunch large and uniform. Ripens about ten days earlier than Concord.

We have investigated many new grapes in the past ten years and found no other grape with so many excellent points.

The Hubbard Grape being of better quality, a better shipper, better size, healthy foliage, a strong grower and earlier ripening makes it a more desirable grape to plant than either Concord or Niagara.

\section{P R I C E S}

Delivered by Parcel Post

Two-year, first-class $\$ 1.50$ each

12.00 per 10

One-year, " 1.00 each

8.00 per 10

Our supply of vines of this new Grape is limited and orders will be filled in rotation.

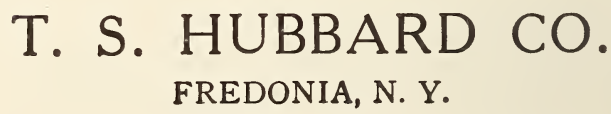




\section{In Praise of The Hubbard Grape.}

Extracts from letters on file.

"This grape leaves a lingering and delicious taste long after you have eaten it."

"The berries are large and filled with a sweet, juicy pulp approaching the richness of Vinifera."

"They are fine flavor, large size and few seeds."

"The flavor and quality is fine. Juicy and sweet. The more I eat the better I like them. A delicious table grape."

"They are by far, superior to any I have seen."

"It is a grand grape; fine bunch, fine berry, finest flavor. I have no reason to change my former opinion of this magnificent grape."

"I consider it one of my best. Strong clean grower, free from mildew. It went through last winter 13 degrees below zero without damage. The fruit is of superior quality with a distinct flavor that is refreshing." 


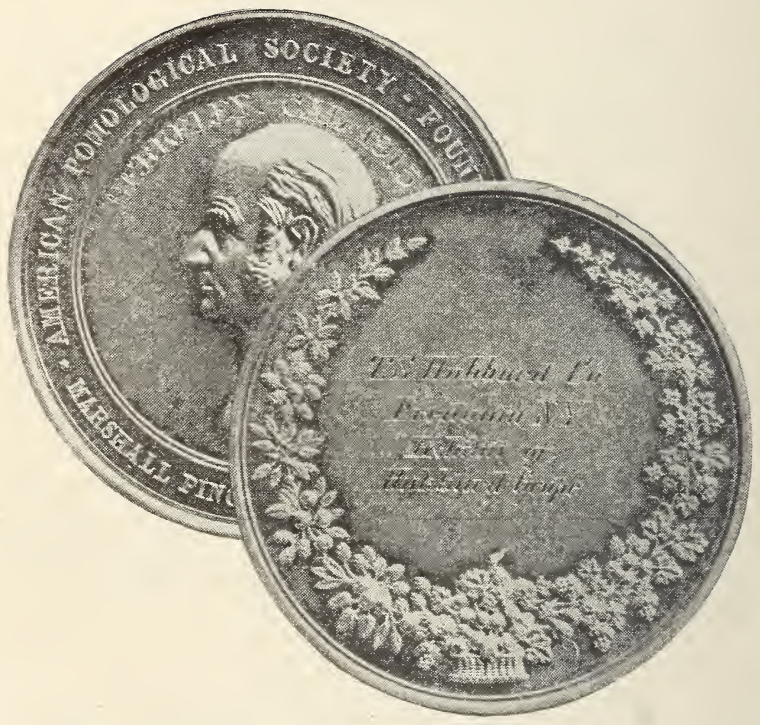

The Hubbard Grape was awarded the Wilder Silver Medal by the American Pomological Society at its meeting in Berkeley, Cal., 1915 